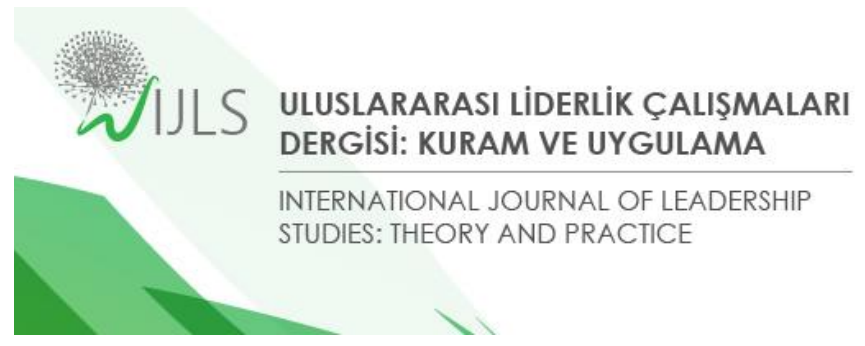

Received Date (Başvuru Tarihi): 06.08.2021

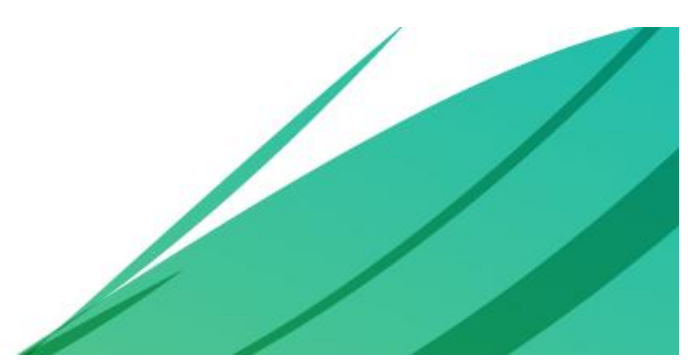

Accepted Date (Kabul Tarihi): 01.09.2021

Article Type (Makale Türü): Research Article / Araştırma Makalesi

doi: $10.52848 / \mathrm{ijl} 1 \mathrm{~s} .892827$

Citation Information: Farooq, M., \& Ahmed, R. (2021). Classroom management practices and learners' academic achievement in public secondary schools in Rubaga division, Kampala-Uganda. International Journal of Leadership Studies: Theory and Practice, 4(3), 163-178. doi: 10.52848/ijls.892827

\title{
CLASSROOM MANAGEMENT PRACTICES AND LEARNERS' ACADEMIC ACHIEVEMENT IN PUBLIC SECONDARY SCHOOLS IN RUBAGA DIVISION, KAMPALA-UGANDA
}

\author{
Miiro FAROOQ $Q^{1} \&$ Rahma AHMED
}

\begin{abstract}
The research evaluated three subconstructs of classroom management namely classroom organization, classroom discipline and classroom instructional methods as predictors of learners' academic achievement. To attain the goal of this research, two hundred fifty-five $(\mathrm{N}=255)$ respondents randomly chosen from two public secondary schools participated in this study. Data was collected from the volunteer using 29 items adopted and adapted from the previous studies analyzed on this subject. A five- point likert scale oscillating from strongly agree (1), to strongly disagree (5) was employed in this study. Simple and multiple linear regression technique was used in data analysis. The research findings generated from the empirical crosssectional survey using simple linear regression indicated that classroom organization offered a prediction rate of .041\% on learners' academic achievement hence no significant relationship (.514). However, the other two sub variables namely classroom discipline and classroom instructional methods were significant (.000). Classroom discipline contributed $.59 \%$ and classroom instructional methods was $.56 \%$ towards learners' academic achievement. Using multiple linear regression, the results further revealed that the model of classroom management and learners' academic achievement deemed fit for the data and represent the intention of the study well.
\end{abstract}

Keywords: Classroom Management, Classroom Organization, Classroom Discipline, Classroom İnstructional Methods, Learners' Academic Achievement.

\section{Introduction}

Of recent, numerous studies towards the concept of learner's academic achievement has been going on among scholars and implementers of educational management practices. Their findings have caused an intense debate on what learner's academic achievement should entail. For instance; some state learner's academic achievement as learners' academic performance, students' achievement, students' engagement, or students' responsibility. However, studies arrived at certain sub-variables "in common" depending on the methodology of data analysis. There is however no unanimous agreement in their findings on what variables should specifically measure and determine in regards to learners' academic achievement. This hence forms a strong background for carrying out a further study in the area of predicting learners' academic achievement with an aim establishing the current situation in Rubaga Division, Kampala, Uganda.

\footnotetext{
${ }^{1}$ Dr., Department of Educational Management and Administration, Faculty of Education Islamic University in Uganda, Email: miirofarooq@gmail.com, ORCID: 0000-0002-1369-7535

${ }^{2}$ Doctoral Student, Department of Educational Management and Administration, Faculty of Education Islamic University in Uganda, E-mail: cadeyrahma833@gmail.com, ORCID: 0000-0003-3205-9827
} 
According to Narad \& Abdullah (2016), academic achievement can be defined as the knowledge gained after assessment has been done by a teacher to meet educational goals as enshrined in the curriculum for a fixed time period. Meanwhile, for these goals to be achieved, it requires continuous assessment or examination results. Academic achievement of students, is not only a guide to the efficacy of a specific school, but also a significant determinant of the future of young people in particular and the nation at large. Learner's outcomes have become a common subject of discussion in all fields of education because they are important for the future state of a particular nation and thus causing scholars to carryout numerous studies to unravel factors that militate against good academic achievement Sunday-Piaro (2018).

Since academic achievement of learners has attracted attention of scholars, parents, policymakers and planners all over the world, Adeyemo (2012), asserts that, the school's primary aim is to help learners achieve academic excellence. Therefore, the school may have other peripheral targets, but priority should be put on sound scholarship achievement. In addition, nearly all stake holders associated with education strive for academic achievement with outstanding academic achievement of children.

It can however be noted that, the factors that have an effect on students' academic achievement at secondary school level are not decisively recognized. They could be many in nature given the divergence of opinions among different scholars of educational management. Some of the influencing factors include students' exceptions towards school, interest in learning environment, study understanding, civic responsibility, self-discipline, building student's capacity, and self-motivation.

In addition, the academic achievements of learners are affected by various factors relevant from one context to another. Socioeconomic status, academic institutional structures and individual student characteristics are the large dimensions of such variables. Ganyaupfu (2013) declares that the teaching methods used by teachers in conducting their lessons have a positive effect on students' academic achievement, Hakizimana (2016) maintains that student academic success is a phenomenon with educational, psychological and sociological connotations. As a consequence, academic achievement cannot be entirely described by either one or two factors, but rather by a mixture of them. Inclusive among which are classroom management practices. Since learners' academic achievement depends on a number of variables, classroom management practices could be enhanced through identifying and manipulating each of such variables.

Classroom management is a key determinant factor for child upbringing in terms of academic excellence and moral uprightness. To achieve academic excellence and moral uprightness schools must ensure that there is a conducive, adequate and sustainable friendly classroom environment which enables both learners and instructors to interact freely. It is therefore implying that classroom environment plays a key role in the education sector. For quality achievement and good marketing strategy, the School Heads need to equip their school with modern and standardized systems that make classrooms a pleasant place for learners' academic achievement. Several scholars define classroom management as indicated below.

Classroom management does not only imply avoiding chaotic environment but also includes establishment of an enabling situation that facilitates both teaching and learning (Nwankwo, Matthew \& Christina, 2019; Oliver, Wehby \& Reschly 2011). It may also mean the efficient and effective way of organizing classroom to achieve the targeted academic goals, because of this, normally unwanted indiscipline challenges are avoided in order to attract good academic scores from learners.

In addition, classroom management can refer to mechanisms that a teacher uses to better his or her teaching and learning sessions. These strategies include, proper sitting arrangement, monitoring 
Classroom Management Practices and Learners' Academic Achievement in Public Secondary Schools in Rubaga Division, Kampala-Uganda

\section{Miiro FAROOQ \& Rahma AHMED}

behaviour, effective learning process, co-coordinating learners' activities, provision of instruction in an interactive way, getting feedbacks from students, acceptance of diversity, favorable instructional material, and classroom organization (Akomolafe \& Adesua, 2016; George, Sakirudeen \& Sunday, 2017; Melesse \& Molla, 2018). Since there is no clear agreement on what classroom management entails while effecting learners' academic achievement, this study employed classroom organization, classroom discipline, classroom instruction methods with a purpose of understanding the extent to which these variables predict learners' academic achievement in a Ugandan context

Furthermore, it is clear that various intertwined factors could be responsible for poor academic achievement among secondary school students. However, it should be noted that these findings differ based on location, academic levels and subjects involved. Therefore, these underlying issues prompted the undertaking of this research. The relevancy and applicability of related research to the context of Public Secondary Schools in Rubaga Division, Kampala, has not been established. Hence, this study seeks, to assess the perceived effect of classroom management practices on learners' academic achievement in selected Public Secondary Schools in Rubaga Division, Kampala Capital City.

\section{Literature}

\section{Learners' Academic Achievement}

In developing cognitive and emotional learning skills among learners, the role of teachers should not be underestimated. This is because teachers' efforts normally set up a foundation for effective classroom management. Schools that often have disorganized and chaotic classroom environment normally tends to fail in achieving reasonable results of learners' due to behavioral threats. Therefore, a healthy environment for both teaching and learning leads to plausible academic achievement (Sunday-Piaro, 2018).

Leaners' academic achievement is the degree at which a leaner, teacher and an institution achieve their intended short- and long-term educational targets. This is normally done through the use of examination results or continuous assessment. The academic achievement of a leaner is normally influenced by several factors like family background, education levels of parents, student's effort, selfmotivation, type and nature of the school, peer group among others. However, many schools of thought put much emphasis on student's education background as a major predictor for future achievements. (Hakizimana, 2016).

For students to achieve plausible outcomes, there must be a mutual and friendly attachment between the students and the teacher. The training and background of a teacher play an important role towards learners' academic achievement. The goal of an education system, is to ensure that children develop skills that lead to competence and productivity in their communities (Hughes, 2014; Y1ldiz, 2017). Since students skills are translated into their future academic excellence, social-emotional and economic transformation, it is an onus on the teachers and administrators to create optimum opportunities for students to excel in their academic endeavors (Kieti, Maithya \& Mulwa, 2017). Furthermore, since teachers play a great role towards learners' academic role, little or none can be achieved without proper classroom management. Several studies done before were so much on the role of teachers towards learner's academic achievement, and it was against this background that results pertaining to classroom management and learner academic achievement evolved.

\section{Classroom Management Practices}

The concept of classroom management practices is an idea that has so far attracted several scholars and experts of educational management theories to invest in its related research studies. Due 
to numerous findings, many scholars have arrived at sub constructs such as classroom organization, discipline and instruction and their significances towards teaching and learning process. Effective implementation of classroom management normally leads to a positive class climate and compassionate environment which can be observed though pupils' socialization while learning thus leading to precautionary discipline management and fruitful teaching (Obwoya, 2013). Meanwhile, classroom management involves the way teachers work, how the class functions, how the teacher and students collaborate and how teaching and learning occur. For students, classroom management means having some control on how the classroom works and understanding visibly the way the teacher and the students cooperate with each other (Chandra, 2015). Also, classroom management is not a condition but a process for both teachers and students. Moreover, some teachers, especially new entrants in the field of teaching may take it as an ever-present concern that requires close monitoring and precautions conditions. Even though it is true that some teachers adapt to classroom management easily, teachers should always take classroom management as a talent and a skill that can be taught or practiced to achieve proficiency.

Despite the fact that much has been written about classroom management, teachers have not been taught detailed and realistic classroom management techniques. Moreover, there has been little focus on "assisting teachers in understanding the issues in successful classroom management and the relationships among various strategies" (Korpershoek et al., 2016). Furthermore, many teachers play with classroom management concepts and techniques by tossing them spontaneously and inconsistently into the classroom. This approach is however generally discouraged because the desired result and hope does not materialize since successful classroom management necessitates specialized skills such as planning, arranging, and focusing on ways to attract aptitude for teamwork and collaboration. Achieving this goal requires a great deal of commitment and willingness to adjust one's thinking and actions to unlearn and relearn new strategies that lead to proper organization of both teaching and learning processes. This implies that a teacher who shows willingness to unlearn, relearn and accommodate new trends of classroom management, will always achieve well organized classroom environment that lead to better learners' academic achievement (Mwaniki, 2012).

\section{Classroom Organization and Learners' Academic Achievement}

Classroom organization is the process through which a teacher plans to put teaching and learning into existence. It is the science of making decisions and taking control of whatever is taking placing during the teaching and learning session. The predetermined goals and objectives of learning are normally attained through the teamwork of both learners and their teacher (Hughes, 2014; Vairamidou \& Stravakou, 2019). The concept of classroom management is wide and many of the studies done reflect variant findings with an effect on learner's academic achievement. For instance it can be observed that characteristics of schools as well as leadership qualities of the principal, teachers' efficacy, motivation needs and the size of the student body all affect student outcomes (Adeyemo, 2012; Y1ld1z, 2013; Zein, 2018).

In line with above, teachers' ability to coordinate classrooms and control their students' actions is crucial for achieving positive educational outcomes. This is because classroom organization is a sophisticated activity that requires organizing or disorganizing activities that may require or discourage certain situations which may arise during the learning environment.

Furthermore, Gacheri (2017) reports that in classrooms that are innovative, neat, and friendly, successful classroom organization promotes independent learning and achievement for all learners. In addition, Igbinoba \& Marvelous (2015) states that rules are a "strong, preventive component of classroom organization and management plans." The purpose of rules is to determine expected habits, reinforcers, and penalties for unacceptable conduct. As a result, concentrating on good classroom 
Classroom Management Practices and Learners' Academic Achievement in Public Secondary Schools in Rubaga Division, Kampala-Uganda

Miiro FAROOQ \& Rahma AHMED

discipline decreases discipline conflicts and leaves the classroom with less interruptions and disturbances. Students' success is affected by how well procedures are set out and taught to them by teachers. In others words, Teachers should arrange classrooms appropriately to promote a healthy learning environment, such as textbook use, chalkboard use, and maintaining classroom cleanliness and tidiness.

In addition Obwoya (2013) the most challenging aspect for schools in terms of classroom organization is to meet the needs of students with varying levels of prior experience and learning rates. Obwoya asserts that some students may fail to understand the lesson because they lack advanced knowledge of the subject matter. As a consequence, teachers must focus on continuity, appropriateness, motivation as well as time if they want to make a big difference in students' achievement. Teachers, in particular, must be mindful that addressing problems relating to one aspect does not result in the creation of new problems relating to another. The failure of the individualized training systems of the 1970s was through frequent loss of quality of instruction, motivation, and time on duty at the correct level of instruction (Cotton, 1994; Franklin \& Harrington, 2019; George et al., 2017; Sowell, 2013b). According to Arens, Morin \& Watermann (2015), when researchers looked into the various learning practices and experiences of gifted children in normal classroom environments, they discovered that the preservation of contextual variables for further analysis via a database-driven record-keeping method that preserves disaggregated data from a series of short observational segments aids the instructor in exercising successful teaching, Obwoya's (2013) research indicates that observational classroom organization, through data management, minimized disruptive activity and enhanced student participation, allows teachers to spend less time addressing misbehavior and more time on instructional instruction. Database management, on the other hand, is a new system that does not extend to public secondary schools in Rubaga division.

\section{Classroom Discipline and Learners' Academic Achievement}

The term "discipline" derives from the Latin "discipulus," which means "to teach and learn." The word has the essence of discipline, which means "to teach someone to follow rules and control their actions or to punish someone in order to preserve order and control" (Dohi et al., 2010). As a result, it is often correlated with punishment for disobedience. Detention and other disciplinary methods "the premise that isolation gives the perpetrator time to reflect on what happened, realize the error of his or her ways, and return to the same situation but with a change of behaviour and attitude" (Moreen, 2018; Gacheri, 2017). According to study, the classroom atmosphere helps students learn more efficiently by offering conducive learning environments (Suleman, Aslan \& Hussain, 2014). Furthermore, numerous studies have shown that the efficiency, continuity, and effectiveness of learners' personal and social experiences affect their academic and social growth. (Coffey, 2003; Hughes, 2014; Sunday-Piaro, 2018; Vairamidou \& Stravakou, 2019). Indiscipline among learners should be uncalled for since it affects their learning outcome and their progress in schools negatively. For instance Stanley (2014), argued that effective schools demonstrate sound inclusive practices which include emphasizing school discipline and collaborative leadership. The school discipline therefore prescribes the standard of behaviour expected of the teachers and the students. Meanwhile, Gacheri (2017) asserts that a law-abiding student is expected to arrive on time for class and wait for the instructor, while a law-abiding teacher is expected to obey all of the time given to him or her on the timetable. Hughes (2014) and Taylor (2009) argue that efficient time management by students and teachers is related to better academic success, and that extra time has a positive effect on academic achievement, In a related review, Stanley (2014) emphasizes that time management can be viewed as a means of controlling and managing one's own performance of multiple tasks within a given time frame. As a result, both student and staff self-attitude and involvement are needed as a norm of time 
management practice in order to enhance academic achievement. It's important to remember that when the classroom atmosphere is positive, teachers are more successful with a diverse community of students who have different skills, learning styles, and cultures. Conversely, another important item to note towards learners' academic achievement is the perception that students performed better in math while they were in a more fun classroom. As a consequence, when the classroom environment is constructive and free of distractions, students are more likely to engage in self-reflective thought and learning. Other researchers have discovered the following correlates of a healthy classroom climate: Lower dropout rates, better attendance records, increased participation, deep learning rather than surface learning, improved grades, and increased motivation to learn (Donnelly \& Lambourne, 2011). Furthermore, research indicates that successful teaching often produces an appropriate level of classroom discipline, which contributes to a favorable climate that discourages students' misbehavior which can interrupt the learning and teaching process. Successful teaching also lowers dropout rates, promotes higher attendance records, encourages greater participation, and leads to deep rather than shallow learning. Meanwhile, Punitive methodologies tend to be of limited value in fostering responsible student conduct and academic outcomes (Donnelly \& Lambourne, 2011), and should be supplemented by constructive and interactive disciplinary methods. Discipline is synonymous with teaching students self-control based on a contract that ties an instructor and a group of students together so that learning can be more successful in this setting. By bargaining, debating, and contracting between teachers and students, an emphasis is placed on student self-regulation.

According to Rahimi and Karkami (2015), students who misbehave in class should always be called out on it and forced to take responsibility for their behavior. When teachers are interested in their students' decision-making or appreciate their good conduct, they behave more responsibly in class, have a more positive influence on their teachers, and believe that the intervention was appropriate (Korpershoek et al., 2016). Furthermore, Gacheri, (2017) asserts that teachers' effective discipline methodologies assist students in learning better because class discipline prevents students from disturbance, which is an emotional and cognitive hazard (Mutungwa \& Orodho, 2015). According to the results of the above studies, instructor management styles boost students' academic performance and keep them on track, engage students in learning, and affect motivation and achievement. "The more those students think their instructor cares about them, the more they will care about the class, and the more likely they will pay attention in class," according to this cycle. In Africa, Rahimi \& Karkami (2015) looked at the use of corporal and verbal punishment to discipline students in Sudanese schools. Teachers used disciplinary measures as a result of the tension and anger they felt at school as a result of the poor school atmosphere and lack of proper facilities management, according to the results. The author, on the other hand, there is no connection between discipline measures and student achievement. According to Ahmad et al. (2017), broad classes are correlated with poor class control, difficulty management, and indiscipline, particularly in secondary schools. Because of the overcrowding, teachers are able to have less lessons and practice, as well as less time for group work and material coverage. Lateness to classes, absenteeism, and failure to complete syllabi were also found to be factors in students' low academic achievement in a study conducted in Ghana (Gacheri, 2017).

Despite the fact that the reviewed studies agree that classroom discipline is a major factor affecting learners' academic achievement, they fail to show which classroom discipline methodologies produce positive results and which ones produce negative results. As a result, the present research aims to analyze particular classroom disciplinary steps and how they affect students' academic achievement in public secondary schools. 
Classroom Management Practices and Learners' Academic Achievement in Public Secondary Schools in Rubaga Division, Kampala-Uganda

Miiro FAROOQ \& Rahma AHMED

\section{Classroom Instruction Methodologies and Learners' Academic Achievement}

A teacher's classroom instructional methodologies are the tools he or she uses to ensure that teaching and learning go as expected. Successful classroom teaching and mentoring usually assist students in discovering their environment with a sense of trust and autonomy, with the end goal of intrinsic self-regulation and increased academic achievement and performance. Teachers' effectiveness in developing a healthy and productive learning atmosphere for students' quality secondary education is based on classroom management methodologies. As a result, teachers should be able to use and apply these methodologies in a number of circumstances that can occur in the classroom (Obwoya, 2013).

An instructor can also use a range of instructional strategies to ensure that students accomplish their objectives without difficulty. As a result, successful teachers distinguish teaching based on the needs of their students. In a typical classroom, Rahimi \& Karkami (2015) suggest how to distinguish students' needs and abilities. Differentiating instruction happens when a teacher changes his or her teaching style in order to have the best possible learning environment. Teachers can usually distinguish four classroom elements based on student preparation, interest, or learning profile, according to Rahimi \& Karkami (2015); depending on the student's preparation, interest, or learning profile, teachers can usually discern four classroom elements: (a) content-what the student wants to learn or how he or she can obtain information; (b) process - activities in which the student participates in order to comprehend or master the material; (c) products - crowning assignments that enable the student to rehearse, and (d) learning environment - the way the classroom functions and feels.

When teaching is based on the learners' own preparation levels, interests, and learning profiles, learners are more effective. According to Vairamidou \& Stravakou (2019), students who are disinterested in something have lower achievement than students who are interested. As a result, students who demonstrate a lot of interest also see their grades increase. Teachers must be mindful of differences between children and take a personal interest in each pupil in order to be successful (Sunday-Piaro, 2018). Teachers must assess what students are capable of and to what extent they are capable. Students' learning can be hindered by learning tasks that are either too difficult or too easy. Those that are too complicated take too much time and do not boost efficiency, whereas those that are too quick are a waste of time (Hughes, 2014; Kieti et al., 2017; Sowell, 2013b; Sunday-Piaro, 2018; Vairamidou \& Stravakou, 2019). Students who are actively involved are obviously more likely to do better academically than students who are not. As a result, teachers need a complex collection of instructional methodologies in order to involve a wide range of students. As a consequence, successful instruction method selection leads to high efficiency. Furthermore, Hughes (2014) argues that teachers can only do this if they are "adequately prepared with information and skills that increase their effectiveness and, as a result, improve learning efficiency."

Furthermore, cooperative teaching and learning methods are important in the classroom for enhancing reading skills and achievement among students with reading disabilities. Teachers intend for students to work in small groups to help one another learn in Cooperative learning takes many types, but the most effective are those in which students work in groups with mixed abilities. After the instructor has presented a lesson, groups of four have daily opportunities to teach each other, and they are accepted based on the learning of all members of the community

Structured teaching has also been suggested as a tool for teaching reading to students with reading disabilities, According to Kausar (2017) and Kapur (2018), emphasized the value of comprehensive and intense instruction and claimed that standardized personalized tuition for failing readers is more successful than eclectic approaches. In order to help learners with reading difficulties develop academically, direct instruction incorporates essential principles of effective instruction, 
Interactive teaching is one form of instruction that fits well within the culturally sensitive pedagogy model (Bua \& Ada, 2015). Interactive teaching involves the use of student-centered learning approaches that require interactions between the students and the teacher (Austin \& Omomia, 2014). Various scholars agree that instructional methodologies will affect learner efficiency, according to the reviewed works. Few of them, however, looked at particular instructional approaches that achieve the desired results in learners' success. As a result, the aim of this study is to see how the classroom instructional technique, as a method of classroom management by teachers, affects the learners' academic success in public secondary school.

\section{Statement of the Problem}

Education has become one of the parameters that determine the development and economic transformation of any country worldwide. It is for this reason therefore that education works as a cornerstone for preparation of a required mass for any society. This process however requires teachers with standardized skills of classroom management and at the same time train and equip learners with knowledge that addresses the global challenges.

Besides, the fourth goal of the United Nations' Sustainable Development Goals (SDGs) is "To ensure inclusive and equitable quality education and promote lifelong learning opportunities for all". It has therefore become important for all countries to ensure that their citizens have access to quality education. Since education plays an important role towards civilization and development, learners are expected to achieve some levels of civility and academic excellence through teachers' effective use of classroom management. For this reason, many educational practitioners, researchers as well as parents and other stakeholders in education are expressing concerns about learners' academic achievement in public secondary schools. In addition, many countries have embarked on curriculum change with an aim of attaining citizens who can compete on the global market. Therefore, for proper implementation of these new curricular, both novice and experienced teachers still struggle with new trends of raising learners' grades especially in public secondary schools. This is because teachers play a greater role towards learners' academic achievement. However, this idea cannot be achieved without proper training of teachers. Today many teachers have undergone further training and studies to improve themselves, however the situation of poor academic achievement seem not to improve world over. Despite teachers' effort of further training in classroom management practices to address deficiencies in improving learners' academic achievement, proper skills of classroom management is still a puzzle for learners academic excellence (Austin \& Omomia, 2014; Bua \& Ada, 2015; Didinya, Ouda \& Ndanu, 2018; Gacheri, 2017; Nzoka \& Orodho, 2014). Even though learners' academic achievement is a cornerstone for improved classroom management, low academic scores and indiscipline are still a major challenge that sometimes call for parents' attention or dismissal of students from school. Since there is scanty information on the predictors of learners' academic achievement in Uganda, this study has been designed to establish the current situation in public secondary schools in Rubaga division.

\section{Objectives}

The objectives of the study were;

1. To examine the effect of classroom organization on leaners' academic achievement,

2. To investigate the effect of classroom discipline management practices on leaners' academic achievement,

3. To assess the influence of classroom instruction methods on leaners' academic achievement, 
Classroom Management Practices and Learners' Academic Achievement in Public Secondary Schools in Rubaga Division, Kampala-Uganda

Miiro FAROOQ \& Rahma AHMED

4. To analyze the extent at which classroom management variables influence learners' academic achievement.

\section{Method}

The sample of the study of 255 was gathered from two public secondary schools in 2019. The studied group involved both school administrators and teachers. This data was gathered through the use of stratified sampling procedure. A likert scale of 1-5 ranging from strongly agree to strongly disagree was employed in the study. To attain the validity of a question after adoption and adaption, experts from the field of educational management and administration were consulted. The reliability of the questionnaire was arrived at through a pilot study conducted on 30 respondents with an intention of improving the questionnaire and at the same time arrive at the needed Cronbach alpha of $\alpha>70$, (Taber, 2018). Furthermore, the survey tool used was distributed by the research student at Master's degree level. 350 questionnaires were distributed and 257 were returned after the entire process. Through the use of regression to clean the data Mahala Nobis checks showed that, two outliers had surpassed the recommended percentage of $16.2 \%$ (McLachlan, 1999). A cross sectional survey tool was used to arrive at the needed data. Meanwhile to arrive at answers to the set hypothesis of the study, regression method of both simple and multiple technique was employed using SPSS version 22.

\section{Data Analysis and Results}

From the data analysis, findings from the demographic characteristics of respondents reflected that $95(37.3 \%)$ were male and $160(62.7 \%)$ were females leading to a total of 255. Age brackets reflected that $36(14.1 \%)$ were below 24 years of age, $56(22.0 \%)$ were between 25 and 30 years of age, $61(23.9 \%)$ were between 30 and 40 years of age, while $60(23.5 \%)$ were between 40 and 50 years of age, and $42(16.3 \%)$ were above 50 years of age. It therefore suggests that the majority of respondents were mature and could make a sound judgment on classroom management practices and leaners academic achievement. In addition, in terms of qualification the majority of respondents held a bachelor's degree and were 119 (46.3\%), while those with Masters' degree were $76(29.6 \%)$ and Diploma $55(21.4 \%)$. In the work experience section, most respondents were over 7 years of experience and these accounted for $24.9 \%$ (64), followed by a group of 3-5 years of work experience $19.8 \%$ (51), then less than 3 years of work experience 18.3\% (47) and lastly 5-7 years of work experience $16.7 \%$ (43). Meanwhile, since the period spent in a school contributes to the growth of understanding and experience, the goal of this study was to evaluate the period of service respondents spent in school with a view to establishing variances in classroom management practices and learners' academic achievement in secondary schools in Rubaga division. According to the results, $22.2 \%$ worked for over 7 years (57) followed by $22.2 \%$ (57) worked for a period of $1-4$ years while $19.8 \%$ (51) worked for a period of 4-7 years. Those who served less than a year were 19.5\% (51)

The data was further analyzed using simple linear regression with the aim of understanding the percentage contributed by each of the sub variables of classroom management towards learners' academic achievement and the results were as follows. To provide answers to the research questions and hypothesis, data was run using both simple and multiple regression techniques. Further analyses were executed as shown below.

Study findings on classroom organization and leaners academic achievement as mentioned in the previous chapter revealed that the hypothesis is not supported by the data of the study. The study findings generated from 255 respondents reflected that hypothesis is not supported as per the simple linear regression analysis used. Whereby, model summary table reflected, R-squared $=.002$, ANOVA table showed that degree of freedom was $1, \mathrm{p}$-value coefficients and $=.514$ and Beta of standardized coefficient was .041. It means that the sub variable classroom organization has no significant 
relationship with learners' academic achievement. Therefore, it can be noticed from this study that it was not appropriate for teachers to dwell so much on this aspect since it carries no or little influence towards the out of learners. This is because the findings indicated that the relationship between the two variables was only predicted at $41 \%(.041)$, moreover without being significant due to .541 figure generated from the data.

These findings were in line with a previous study done Salamat et al. (2018), reflected that there is no connection between classroom organization and students' academic achievement. Hence rendering the model unfit and insignificant. However, in the study done by Nisar, Khan \& Khan (2019), reflected variant finding whereby, the predictors of learners' academic achievement were based on involvement and personal effort as subcomponents of classroom organization. Meanwhile, another study emphasized that learners' participation through pairs, tasks were the key issues that influenced classroom organization (Escabias \& Ortega-Martín, 2006; Nisar, et al., 2019). It can therefore be argued that even though the study found that there is no significant relationship between classroom organization and leaners academic achievement scholars from previous studies have divergent finding on this variable.

To arrive at answers to the casual relationship between classroom discipline management and leaners academic achievement, the results of the research on classroom discipline management and leaners academic achievement showed from the model summary that R-squared was .345, adjusted Rsquared .343, ANOVA and Coefficient tables showed the causal relationship was significant with pvalue of .000 , Beta $=.588$ shown that the assumption is supported. The findings from 255 respondents showed that the hypothesis "classroom discipline management has significant relationship with leaners academic achievement". This is because the results suggested that the relationship between the two variables was predicted at 58\% (.588) towards learners" academic achievement. The results were in agreement with the findings of the study done in Kenya by Simba et al. (2016), this study employed 34 schools randomly selected by use of a questionnaire and found out that discipline had a greater contribution towards learner's academic performance even though he called upon the teachers to improve where scores seemed to have low contributions. Similarly a study done by Stanley (2014) found out that schools in Nigeria were using corporal punishment to cause an impact on learner's academic performance. However, this method also caused variant outcomes on the side of the learners. Also similar findings were found by George et al. (2017) in their studies and encouraged both staff and parents to enforce discipline if their learners are to succeed academically. Likewise, Bua \& Ada (2015) in their study about classroom discipline and learners' academic achievement found out that for students to pass science and mathematics subjects, teachers used motivation, and innovative ideas towards learners. From this background it can therefore observed that discipline plays a greater role towards molding learners in their academic endeavors and future aspirations.

To answer whether classroom instruction methods and leaners' academic achievement have a significant relationship, the finding of the study on classroom instruction method and leaners academic achievement showed from the model summary that $\mathrm{R}=.561$, R-squared $=.314$, adjusted R-squared= .312 , degree of freedom $=1$, standardized Beta $=.561 \mathrm{p}$-value $=.000$, the hypothesis "classroom instruction method had a significant effect towards leaners academic achievement." This is because the results generated between the two sub variables was $56 \%$ (.561) towards leaners academic achievement.

Several studies about this relationship of classroom instruction and learner's academic achievement have been done previously and their findings varied due to topics, site, population and data analysis methods. For instance; in the study conducted by Akama (2015) through the use of mixed methods, it was established that instructional strategies of managing classroom play an 
Classroom Management Practices and Learners' Academic Achievement in Public Secondary Schools in Rubaga Division, Kampala-Uganda

Miiro FAROOQ \& Rahma AHMED

important role towards leaner's academic achievement especially when the teachers employs experiments, however when there is lack of proper training among teachers, learners are bound to fail in their aspirations. Conversely, Vincent \& Udeme, (2014) and Munawaroh, (2017) found different styles of teaching in their study at university level. This is due to their statements that instructional strategies employed by institutions normally lead to significance differences whenever employed by a particular instructor.

To understand the extent at which classroom management variables influence learners' academic achievement, data using multiple regression by running the three sub variables of classroom management (classroom organization, classroom discipline management, classroom instruction method) against learners 'academic achievement. Results from the model summary showed that $\mathrm{R}=.718$, R-squared $=.516$, Adjusted $\mathrm{R}=.510$, ANOVA table reflected the degree of freedom as 3 and $\mathrm{p}$ p-value $=.000$. The coefficient table reflected that the standardized Beta for the casual relationship between classroom organization and academic achievement as -.060 with a $\mathrm{p}$-value $=.182$, classroom discipline and academic achievement with a Beta of .462 and p-value $=.000$, classroom instruction methods Beta $=.440, \mathrm{p}$-value $=.000$. This was done with an intention of establishing whether the hypothesized model fits the data and as well represents the intention of the study. It can be observed that, the model summary of the general multiple regression the entire model of the study of both the independent and dependent variables predicts R-squared as .516 which is $56 \%$ of the outcome. Also, the findings reflected that the model fits the data since the ANOVA table displayed the significance level of the study with a p-value of. (000) and degree of freedom reflected 3. Meanwhile, the table of coefficients showed percentage of the Standardized Coefficients Beta for each of the sub variables that include classroom discipline management contributed 46\%, p-value (.000) of the model predicted outcome, classroom instruction $44 \%$ with a p-value (.000) and classroom organization $6 \%$, p-value (.182) towards the dependent variable of learners' academic achievement.

In reference to the above findings of the model about classroom management and learners' academic achievement, researchers found variant findings due to methodology, population, sample and location of respondents. For instance; found that classroom management has a significant influence towards academic achievement however, these studies used a few of sub variables of classroom management to enhance their studies (Lu et al., 2018; Rugutt \& Chemosit, 2005; Sowell, 2013a). Hence causing different studies' findings. It can therefore be observed that the model of this study fitted that the data even though one of the factors did not show any significant relationship towards academic achievement. This can be tailored to differences among respondents, time of data collection and the level of exposure among respondents.

\section{Conclusions}

In Uganda, many schools seem to have inappropriate number of staff needed with skills that do not line with the needs of the time. However, the situation appeared different to findings of the study as indicated below even though one of the objectives was in line with above situation. Classroom organization according to study findings reflected that, it has no significant effect on learners' academic achievement. The results further reflected that classroom discipline management had a significant effect on leaners academic achievement. The results similarly showed that classroom instructional methods have a significant effect on learner's academic achievement. Lastly the model from the results showed good fitness of the data and presented the intention of the study well since most of the sub variables were significant and had a positive effect on learners' academic achievement. 


\section{Recommendations}

Since there were no significant relations between classroom organization and learners' academic achievement, a similar study can be done in other areas of the country with an aim of involving more stakeholders in the study and establish if there is a correlation between the two constructs. In line with objective classroom discipline management has a significant effect on learners' academic achievement. There is need to conduct similar studies with a bigger number of respondents in order to further establish whether discipline management still holds a significant relation towards learners' academic achievement and then base on the wider findings to formulate more policies that can help teachers manage discipline effectively. Since classroom instructional method is the gist of any academic excellence of learners and teachers' effectiveness in managing classroom management. The study findings reveal that there was significant relationship between the two variables and therefore head teachers and stakeholders of all education institutions should continue to improve the policies for its implementation so as to prepare learners with both soft and hard skills of globalization. Conversely, the study findings revealed that the model on the classroom management practices towards learner's academic achievement deemed fit for the data. However, one of the variables (classroom organization) did not significantly predict the out. Another study can be done with a big sample and evaluate whether it plays a significant role. The study was limited in number of respondents due to several reasons enumerated above, therefore it is recommended that further studies are done on a similar topic with longitudinal survey technique and mixed methods of data analysis.

\section{Statement of Research and Publication Ethics}

The article was written in accordance with the principles of research and publication ethics. Since the data were collected in 2019, Ethics Committee Permission was not obtained.

\section{Authors' Contribution Rates}

Two authors contributed to the article at the same rate, and other authors and organizations did not support the writing process.

\section{Statement of Interest}

The authors have no conflict of interest with any person or organization. 
Classroom Management Practices and Learners' Academic Achievement in Public Secondary Schools in Rubaga Division, Kampala-Uganda

Miiro FAROOQ \& Rahma AHMED

\section{References}

Adeyemo, S. A. (2012). The relationship between effective classroom management and students' academic achievement. European Journal of Educational Studies, 4(3), 367-381.

Ahmad, S., Hussain Ch, A., Ayub, A., Zaheer, M., \& Batool, A. (2017). Relationship of classroom management strategies with academic performance of students at college level. Bulletin of Education and Research, 39(2), 239-249.

Akama, M. K. (2015). Instructional strategies and their influence on pupils' academic performance in science subject at primary schools in ruiru sub-county, Kiambu County, Kenya. Research Project Submitted in Partial Fulfillment of the Requirements of the Award of Master Degree.

Akomolafe, C. O., \& Adesua, V. O. (2016). The Impact of physical facilities on students' level of motivation and academic performance in senior secondary schools in south. Journal of Education and Practice, 7(4), 38-42.

Arens, A. K., Morin, A. J. S., \& Watermann, R. (2015). Relations between classroom disciplinary problems and student motivation: Achievement as a potential mediator? Learning and Instruction, 39, 184-193. https://doi.org/10.1016/j.learninstruc.2015.07.001

Austin, O. O., \& Omomia, T. A. (2014). Perceived impact of classroom management on effective teaching: A study of five schools in education district 11, Lagos State, Nigeria. Europian Scientific Journal, 10(22), 309-320.

Bua, F. T \& Ada, J. (2015). Influence of classroom management on students' academic achievement in science and mathematics in oju local government area of Benue State. African Journal of Arts, Science and Educational Issues, 4(4), 36-40.

Chandra, R. (2015). Classroom management tools for effective teaching. International Journal of Education and Psychology Research, 4(4), 13-15.

Chinyere, V. A., Okoro, B. C., \& Eric, O. (2019). Effect of authoritative classroom management style on performance of students in public secondary schools in imo state. International Journal of Management and Marketing Systems, 7(2), 42-64.

Coffey, V. (2003). The organisational culture and effectiveness of companies involved in public sector housing construction in Hong Kong. CIB TG 23 International Conference, October, 1-11.

Cotton, K. (1994). School improvement research series educating for citizenship. Wood 1988, 1-39.

Didinya, E., Ouda, J. B., \& Ndanu, C. (2018). Effect of performance appraisal of teachers on academic performance of students in public secondary schools in Hamisi Sub-County, Vihiga County, Kenya. Journal of Popular Education in Africa, 2800 (August), 0-16.

Dohi, K., Shimizu, A., Takahashi, R., Osada, T., Asada, Y., \& Kanazashi, T. (2010). An analysis of Longman Dictionary of contemporary English, Fifth Edition. Lexicon, 40(2005), 85-187. https://globalex.link/wp-content/uploads/2019/08/Lexicon-40_003.pdf

Donnelly, J. E., \& Lambourne, K. (2011). Classroom-based physical activity, cognition, and academic achievement. Preventive Medicine, 52(SUPPL.), 36-42.

Escabias, E. R., \& Ortega-Martín, J. L. (2006). The importance of organisation and classroom management in foreign language teaching: an empirical study of teachers and students' perceptions. The International Journal of Learning: Annual Review, 12(3), 259-276. https://doi.org/10.18848/1447-9494/cgp/v12i03/46807

Franklin, H., \& Harrington, I. (2019). A review into effective classroom management and strategies for student engagement: teacher and student roles in today's classrooms. Journal of Education and Training Studies, 7(12), 1. https://doi.org/10.11114/jets.v7i12.4491

Gacheri, N. P. (2017). Influence of classroom management practices on students academic achievement in public secondary schools in Tharakanithi County, Kenya. Master of Education Administration Degree of Kenyatta Unıversity. 
Ganyaupfu, E. M. (2013). Factors influencing academic achievement in quantitative courses among business students of private higher education institutions. Journal of Education and Practice, 4(15), 57-65. http://www.iiste.org/Journals/index.php/JEP/article/view/6820

George, I. N., Sakirudeen, O., \& Sunday, H. (2017). Effective classroom management and students' academic performance in secondary schools in Uyo local government area of Akwa Ibom state. Research in Pedagogy, 7(2), 43-56. https://doi.org/10.17810/2015.47

Hakizimana, E. (2016). Classroom management and students' academic performance in secondary schools in Nyamagabe district, Rwanda. A Research Project Submitted in Partial Fulfillment of the Requirements for the Award of the Degree of Master (Issue May).

Hughes, K. (2014). The effect of classroom management strategies on math fluency growth rate. ProQuest Dissertations and Theses, 56. https://search.proquest.com/docview/ $\underline{1562519817 \text { ? accountid }=15690}$

Igbinoba, O. K., \& Marvelous, A. I. (2015). The impact of classroom management on students' academic performance in selected junior secondary schools in municipal area council, Abuja. International Journal of Education and Research, 3(9), 141-154.

Kapur, R. (2018). Factors influencing the student's academic performance in secondary schools in India. 1(April), 25. Retrieved from https://www.researchgate.net/publication 1324819919 Factors Influencing the Students Academic Performance in Secondary Scho ols in India

Kausar, A. (2017). Effect of classroom environment on the academic achievement of secondary school students in the subject of Pakistan studies at secondary level in effect of classroom environment on the academic achievement of secondary school students in the subject of Pa. Journal of Education and Practice, 8(August), 55-63.

Kieti, J. M., Maithya, R., \& Mulwa, D. M. (2017). Influence of Administrative Practices on Students' Academic Performance in Public Secondary Schools in Matungulu Sub-County, Kenya. International Journal of Education and Research, 5(1), 11-22.

Korpershoek, H., Harms, T., de Boer, H., van Kuijk, M., \& Doolaard, S. (2016). A meta-analysis of the effects of classroom management strategies and classroom management programs on students' academic, behavioral, emotional, and motivational outcomes. Review of Educational Research, 86(3), 643-680. https://doi.org/10.3102/0034654315626799

Lu, O. H. T., Huang, A. Y. Q., Huang, J. C. H., Lin, A. J. Q., Ogata, H., \& Yang, S. J. H. (2018). Applying learning analytics for the early prediction of students' academic performance in blended learning. Educational Technology and Society, 21(2), 220-232.

McLachlan, G. J. (1999). Mahalanobis distance. Resonance, 4, 20-26.

Melesse, S., \& Molla, S. (2018). The contribution of school culture to students' academic achievement: the case of secondary and preparatory schools of Assosa Zone, Benshangul Gumuz Regional State, Ethiopia. Research in Pedagogy, 8(2), 190-203.

Moreen, N. (2018). Classroom management and academic performance of students in najja high school Kabowa Kampala district, Ugandae (Issue September).

Munawaroh. (2017). The influence of teaching methods and learning environment to the student's learning achievement of craft and entrepreneurship subjects at vocational high school. International Journal of Environmental and Science Education, 12(4), 665-678.

Mutungwa, J. M., \& Orodho, J. A. (2015). Resource management challenges and learners academic performance in national examinations: what are the coping strategies in public primary schools in Makindu District, Makueni County, Kenya? IOSR Journal Of Humanities And Social Science, 20(4), 25-32. https://doi.org/10.9790/0837-20452532 
Classroom Management Practices and Learners' Academic Achievement in Public Secondary Schools in Rubaga Division, Kampala-Uganda

Miiro FAROOQ \& Rahma AHMED

Mwaniki, F. (2012). Influence of classroom management on student academic performance in history and government in public secondary schools in Embu east district. A Research Project Reportsubmitted in Partial Fulfillment of the Requirement for the Award of Masters of Arts Degree. http://erepository.uonbi.ac.ke/

Nwankwo, N. D. I., Matthew, M. O., \& Christiana, M. A. (2019). Extent of teachers' classroom management practices for quality teaching and learning in secondary schools in ebonyi state. International Journal of Humanities and Social Science, 9(1). https://doi.org/10.30845/ijhss.v9n1p12

Narad, A., \& Abdullah, B. (2016). Academic performance of senior secondary school students: Influence of parental encouragement and school environment. Rupkatha Journal on Interdisciplinary Studies in Humanities, 8(2), 12-19.

Nisar, M., Khan, I. A., \& Khan, F. (2019). Relationship between classroom management and students academic achievement. Pakistan Journal of Distance \& Online Learning, 5(1), 209-220.

Nzoka, J. T., \& Orodho, J. A. (2014). School management and students' academic performance : how effective are strategies being employed by school managers in secondary schools in Embu. International Journal of Humanities and Social Science, 4(9), 86-99.

Obwoya, M. (2013). Management and achievement classroom management and learners' achievement in secondary schools in Kitgum Town Council.

Oliver, R. M., \& Reschly, D. J. (2007). Effective classroom management: Teacher preparation and professional development. National Comprehensive Center for Teacher Quality, 1-24. http://tqcenter.learningpt.org/topics/effectiveClassroomManagement.pdf

Oliver, R. M., Wehby, J. H., \& Reschly, D. J. (2011). Teacher classroom management practices: effects on disruptive or aggressive student behavior. Campbell Systematic Reviews, 7(1), 155. https://doi.org/10.4073/csr.2011.4

Rahimi, M., \& Karkami, F. H. (2015). The role of teachers' classroom discipline in their teaching effectiveness and students' language learning motivation and achievement: A path method. Iranian Journal of Language Teaching Research, 3(1), 57-82.

Rugutt, J., \& Chemosit, C. (2005). A study of factors that influence college academic achievement: A structural equation modeling approach. Journal of Educational Research \& Policy Studies, $5(1), 66-90$.

Salamat, L., Ahmad, G., Bakht, M. I., \& Saifi, I. L. (2018). effects of E-Learning on students' academic learning at university level. Assian Innovative Journal of Social Sciences \& Humanities, 2(2)(July), 1-12.

Simba, N. O., Agak, J. O., \& Kabuka, E. K. (2016). Impact of discipline on academic performance of pupils in public primary schools in Muhoroni Sub-County, Kenya. Journal of Education and Practice, 7(6), 164-173.

Sowell, H. K. (2013a). Classroom Management Strategies: The Impact on Schools.

Sowell, H. K. (2013b). Classroom management strategies: The impact on student achievement. In Dissertations and Theses.

Stanley, E. O. (2014). Discipline and academic performance (A study of selected secondary schools in Lagos, Nigeria). International Journal of Academic Research in Progressive Education and Development, 3(1). https://doi.org/10.6007/ijarped/v3-i1/758

Suleman, Q., Aslam, H. D., \& Hussain, D. I. (2014). Effects of Classroom Physical Environment on the Academic Achievement Scores of Secondary School Students in Kohat Division, Pakistan. International Journal of Learning and Development, 4(1), 71. https://doi.org/10.5296/ijld.v4i1.5174 
Sunday-Piaro, M. (2018). Classroom management and students' academic performance in public secondary schools in rivers state. International Journal of Scientific Research in Education, 11(5), 940-963.

Taber, K.S. (2018). The use of Cronbach's Alpha when developing and reporting research instruments in science education. Research in Science Education, 48, 1273-1296.

Taylor, B. (2009). Classroom management impacts student achievement: tips to thrive and survive. Online Submission, 1-8.

Vairamidou, A., \& Stravakou, P. (2019). Classroom management in primary and secondary education literature review. Journal of Education and Human Development, 8(2). https://doi.org/10.15640/jehd.v8n2a7

Vincent, E. O., \& Udeme, T. A. (2014). Instructional strategies and students academic performance in electrical installation in technical colleges in Akwa Ibom State: Instructional skills for structuring appropriate learning experiences for students. International Journal of Educational Administration and Policy Studies, 6(5), 80-86. https://doi.org/10.5897/ijeaps2014.0347

Wiktorowicz, J. (2016). Exploratory factor analysis in the measurement of the competencies of older people. Ekonometria Econometrics, 4(54). https://doi.org/10.15611/ekt.2016.4.03

Yildız, N. G. (2013). Classroom management and student achievement: a study on five elementary classrooms. Journal of Chemical Information and Modeling, 53(9), 1689-1699. https://doi.org/10.1017/CBO9781107415324.004

Zein, S. (2018). Classroom management for teaching English to young learners. The Routledge Handbook of Teaching English to Young Learners, December 2018, 154-168. https://doi.org/10.4324/9781315623672-11 